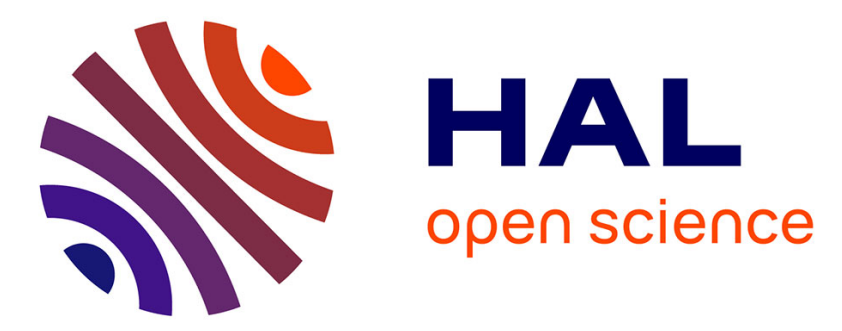

\title{
The use of small-format and low-altitude aerial photos for the realization of high-resolution DEMs in mountainous areas: application to the Super-Sauze earthflow
}

J.B. Henry, Jean-Philippe Malet, Olivier Maquaire, Pierre Grussenmeyer

\section{To cite this version:}

J.B. Henry, Jean-Philippe Malet, Olivier Maquaire, Pierre Grussenmeyer. The use of small-format and low-altitude aerial photos for the realization of high-resolution DEMs in mountainous areas: application to the Super-Sauze earthflow. Earth Surface Processes and Landforms, 2002, 27, pp.13391350. 10.1002/esp.411 . halshs-00260644

\section{HAL Id: halshs-00260644 \\ https://shs.hal.science/halshs-00260644}

Submitted on 26 May 2008

HAL is a multi-disciplinary open access archive for the deposit and dissemination of scientific research documents, whether they are published or not. The documents may come from teaching and research institutions in France or abroad, or from public or private research centers.
L'archive ouverte pluridisciplinaire HAL, est destinée au dépôt et à la diffusion de documents scientifiques de niveau recherche, publiés ou non, émanant des établissements d'enseignement et de recherche français ou étrangers, des laboratoires publics ou privés. 
HENRY, J.-B., MALET, J.-P., MAQUAIRE, O., GRUSSENMEYER, P., (2002). The use of small-format and low-altitude aerial photos for the realization of high-resolution DEMs in mountainous areas: application to the Super-Sauze earthflow (Alpes-de-Haute-Provence, France), Earth Surface Processes and Landforms ISSN: 0197-9337, Volume 27, Issue 12, pp. 1339-1350.

\title{
TECHNICAL COMMUNICATION
}

\section{The use of small format and low-altitude aerial photos for the realization of high-resolution DEMs in mountainous areas. Application to the Super-Sauze earthflow (Alpes-de-Haute-Provence, France).}

\author{
J.-B. HENRY ${ }^{1, *}$, J.-P. MALET ${ }^{2}$, O. MAQUAIRE ${ }^{2}$ and P. GRUSSENMEYER ${ }^{1}$ \\ ${ }^{1}$ Laboratoire d'Etudes et de Recherche en Génie Civil de Strasbourg (LERGEC), \\ Equipe Photogrammétrie et Géomatique, Ecole Nationale Supérieure des Arts et \\ Industries de Strasbourg (ENSAIS), 24, boulevard de la Victoire, F-67084 Strasbourg, \\ France \\ ${ }^{2}$ Institut de Physique du Globe de Strasbourg (IPGS), UMR 7516 CNRS-ULP, 3, rue \\ de l'Argonne, F-67083 Strasbourg, France.
}

\begin{abstract}
Geomorphologists have to make choices and compromises, as acquisition techniques of geometrical information are numerous, depending on the specific complexity of the targeted three dimensional objects and the requirements of the end user. This article presents the methodology and the results over a well known and documented site. This ready-to-use, low altitude, aerial photo methodology reveals itself to be a satisfying compromise between cost, accuracy and difficulty of implementation. The selected equipment package is light enough to enable a quick reaction to unexpected events and the tools and methods are competitive with field acquisition techniques. An evaluation has demonstrated a sub-metric accuracy for the final result.
\end{abstract}

KEY-WORDS: digital elevation model; automated digital photogrammetry; small-format semi-metric camera; terrain modelling; earthflow.

\section{INTRODUCTION}

Today, a lot of morphological or hydrological studies require 3-D, high resolution surface models: first of all as a simple visualisation tool, then as a tool to analyse morphological processes, and finally as geometrical boundary conditions of modelling (Goudie, 1990; McCullagh, 1998). In the last decade, positioning techniques at various time and spatial scales have greatly progressed (Lane et al., 1998), particularly in the fields of dynamic cartography, the 3-D representation of geomorphological processes, and the generation of Digital Elevation Models (DEM). The geomorphologist can use several techniques to generate DEM's, according to the required scale, quality and resolution. These methods can be: radar interferometry for scales higher than the 1/10000 ${ }^{\mathrm{e}}$ (Fruneau et al., 1996; Mohr et al., 1998); the Global Positioning System if the relief is very marked or if many obstacles exist (Higgit and Warbutton, 1999; Mendonça Santos et al., 2000); or digital photogrammetry with various resolutions according to the scale of the photographs (Chandler, 1999; Weber and Herrmann, 2000; Westaway et al., 2000). In this last case, the quality of the DEM will depend on the acquisition of precise ground control points, homogeneously distributed over the area.

Digital photogrammetry has already shown great abilities in DEM generation and has successfully been applied with low-cost to fluvial geomorphology (Pyle et al., 1997), hydrological modelling (Webb, 1995; Walker and Willgoose, 1999), soil roughness analysis (Chandler, 1999; Hancock and Willgoose, 2001), gully surveying (Palacio-Prieto and López-Blanco, 1994), avalanche volume quantification (Ammann, 1999), and landslide displacement surveying with multi-date DEMs (Powers et al., 1996; Weber and Herrmann, 2000).

The objective of this paper is to propose a case-based study over difficult terrain, of a ready-to-use and lowcost methodology to generate detailed DEM's ( $\pm 50 \mathrm{~cm}$ in planimetry and altimetry). This study is founded on the fact that low-cost semi-metric photogrammetry has been employed by geomorphological researchers over

\footnotetext{
*Now at Service Régional de Traitement d'Image et de Télédétection (SERTIT), Pôle API, Boulevard S. Brandt, F-67400 Illkirch-Graffenstaden, France.
} 
HENRY, J.-B., MALET, J.-P., MAQUAIRE, O., GRUSSENMEYER, P., (2002). The use of small-format and low-altitude aerial photos for the realization of high-resolution DEMs in mountainous areas: application to the Super-Sauze earthflow (Alpes-de-Haute-Provence, France), Earth Surface Processes and Landforms ISSN: 0197-9337, Volume 27, Issue 12, pp. 1339-1350.

many years (Petrie and Price, 1966; Welch and Jordan, 1983; Chandler et al., 1989). The methodology is orientated towards geomorphologists not specialised in photogrammetry, but willing to invest time to understand its basic principles. Firstly, different solutions are presented for DEM generation from aerial photographs for various origins and scales. Then, the chosen solution is treated, covering its principles, advantages and constraints. Material choices will be presented and justified, regarding their influences on the quality of the photogrammetric restitution. Afterwards, the production of the photos will be described, covering the process with a particular emphasis on crucial points which guarantee a $50 \mathrm{~cm}$ altimetric accuracy. The method is successfully applied to the 3-D modelling of the Super-Sauze earthflow and its environs (Alpes-de-HauteProvence, south-eastern France).

\section{SOLUTIONS AVAILABLE TO PRODUCE DEM's}

At regional scales, particularly in climatology and hydrology, DEM's are often produced from national altimetric databases (obtained from digitising height contours on 1/30000 to 1/25000 maps). Nevertheless, the spatial resolution $(75 \mathrm{~m})$ and accuracy (2.5 m approximately in altitude) of these databases are insufficient in many cases, especially in mountainous areas, and are not often available throughout a national territory.

For studies on a catchment scale, several other solutions are available (Fig.1). A first solution consists of a photogrammetric reconstitution on pairs of metric air photographs (e.g. scales of 1/25000 or 1/30000 in $23 \times 23$ $\mathrm{cm}$ format from IGN France). In very high relief, the technique offers a precision of approximately $3 \mathrm{~m}$ in planimetry and $10 \mathrm{~m}$ in altimetry (Weber and Herrmann, 2000). These missions are realised at high altitude, with a specific schedule, and hence have very poor repetitivity and reactivity.

A second solution, which improves the model's spatial resolution and 3-D accuracy, requires a pair of vertical, helicopter-borne photographs, in a small or medium format (50 $\mathrm{mm}$ x $60 \mathrm{~mm}, 24 \mathrm{~mm}$ x $36 \mathrm{~mm}$ ), at a scale of $1 / 500$ or less, whose cost of acquisition can be crippling (1000 € per hour).

A third solution, cheaper than helicopter-borne photography, is a photographic campaign at low flight altitudes (below $200 \mathrm{~m}$ ) from a remotely controlled plane, which can be used to reach inaccessible or dangerous areas. This method's relief restitution, from a small camera format, can be very precise, approx. $10 \mathrm{~cm}$ (Tapponnier et al., 1999). However, this methodology implies practical constraints: the drones are sight controlled and require a flat runway within the pilot's field of view. Moreover, in the absence of both a GPS receiver and an advanced radio-control system on the drone, photographs can only be taken in one strip.

Finally, a fourth solution, which is cheaper and offers a great advantage in the response time for photograph production, consists of taking photos from a plane, with small cameras in a quasi-vertical position. According to the requisite resolution and precision, the various photographs can then be assembled. Over the last decade, several attempts were made, in an experimental (Graham and Read, 1984) or operational manner (Heimes et al., 1993; Rowe et al., 1999).

Generally, an accurate small sized air-photo system is based on a metric camera, which has a stable internal orientation known with respect to its fiducial marks. Nevertheless, non-metric cameras, also called amateur or standard, without fiducial marks can be used in photogrammetry even though their internal orientation is partially unknown and/or unstable. Compared to metric cameras, the latter have the following advantages (Karara, 1980): flexibility in the choice of the focal distance, availability of motorized cameras which enable fast shooting, their low cost, reduced size and weight, and the use of amateur films $(24 \times 36 \mathrm{~mm})$. Their disadvantages are, in particular: the lack of fiducial marks (even if they can be introduced a posteriori, in the case of a semi-metric camera), the instability of the internal orientation parameters and lens quality, which is generally optimised for high resolutions compromising geometrical accuracy (potential irregular distortions). The transformation from an amateur into semi-metric camera can be performed by specialised companies, costing up to $1500 €$. 
HENRY, J.-B., MALET, J.-P., MAQUAIRE, O., GRUSSENMEYER, P., (2002). The use of small-format and low-altitude aerial photos for the realization of high-resolution DEMs in mountainous areas: application to the Super-Sauze earthflow (Alpes-de-Haute-Provence, France), Earth Surface Processes and Landforms ISSN: 0197-9337, Volume 27, Issue 12, pp. 1339-1350.

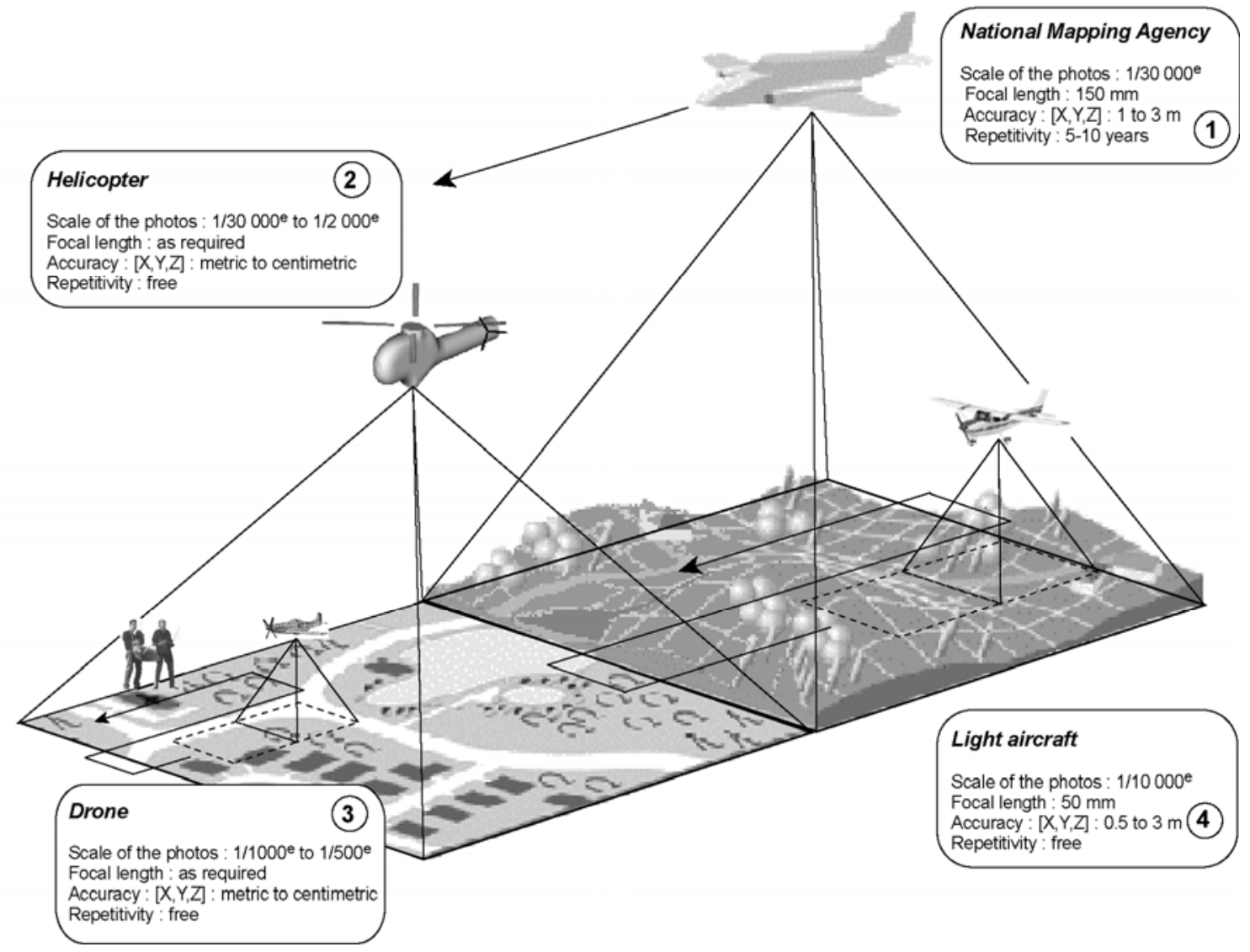

Fig. 1 - Different modes of photo acquisition and final accuracy of the processed DEM.

According to the photogrammetric process used, it is impossible to formalize the overall precision of a DEM, which nevertheless can be estimated. Kraus and Waldhäusl (1998) affirm that the main parameters influencing the final precision are: the photographs' scale and resolution, the density of ground control points measured in situ by geodetic methods and their distribution accounting for more or less hilly nature of the area, and the camera positioning accuracy. Thus, the required precision must be defined, which will guide the choice of the photogrammetric method to be employed (definition of the precision/cost ratio).

\section{METHODS AND TREATMENTS}

As photogrammetric processing is based on spatial resection and similarity methods (where small deviations can generate large errors), specific attention has to be paid to both the preparation and realisation of the photographic flight and the photogrammetric processing itself.

Principle of stereo-restitution: bundle block adjustment method

Stereo-restitution principles indicate that, a minimum of three ground control points are needed in order to work on a stereo-model (a pair of photos). Aero-triangulation is an extension of stereo-restitution methods, that enables a global restitution of a block of photos and the reduction of ground control points. This creates the possibility of working over terrain with a poor geodetic point density. Bundle block adjustment is an iterative method based on the use of photo coordinates as observations. Then, the application of the central projection method (Kraus and Waldhäusl, 1998) enables the conversion of these observations into terrain coordinates in one step. This requires a block of photos with at least $60 \%$ overlap and $20 \%$ side-lap (Fig. 2). Another important advantage of this method is the ability to include additional parameters in computations, such as inner orientation elements or photo deformation parameters, caused by optics, film, multiple refraction anomalies or any other source of error. Consequently, any systematic error can be taken into account. This is particularly interesting when using an amateur or semi-metric camera, even if they had been calibrated prior to the photo acquisition.

The input to aero-triangulation calculations consists of picking both ground control and tie points (used to join photos together along and between strips), and their quality affects the reliability of the overall model. It uses explicitly the mean squares principle, based on measurement redundancy. So, point measurement error detection 
HENRY, J.-B., MALET, J.-P., MAQUAIRE, O., GRUSSENMEYER, P., (2002). The use of small-format and low-altitude aerial photos for the realization of high-resolution DEMs in mountainous areas: application to the Super-Sauze earthflow (Alpes-de-Haute-Provence, France), Earth Surface Processes and Landforms ISSN: 0197-9337, Volume 27, Issue 12, pp. 1339-1350.

is carried out using root mean squares errors. Finally, the main advantage of processing by the bundle block adjustment is to produce a global and homogeneous result over the whole area. So, the quality of the final digital elevation model (DEM) is obtained by the union of each DEM generated from each couple. This has been recognised as the most accurate of aero-triangulation methods (Ackermann and Schwidefsky, 1974), and is also well adapted for amateur photos (Kraus and Waldhäusl, 1998).

\section{Inner orientation.}

Inner orientation consists of very accurately defining (close to a $\mu \mathrm{m}$ ) the photo coordinate system, in which measurements will be taken. This operation is enabled by the presence of fiducial marks inside the camera. Calibration results must be integrated (radial distortions, principal point location).

Preparing the photographic flight: stereo-preparation.

To enable computation, markers have to be placed on homogeneously distributed points in the field (Fig. 2b) and their 3-D coordinates must be geodetically determined. In order to facilitate the beginning of the calculation, a dense network of ground control points should be acquired for one stereo-couple (Kraus and Waldhäusl, 1998). To position the plane for each flight path, a GPS receiver seems to be the optimum solution.

\section{Digital Elevation Model generation.}

Many photogrammetric software packages, such as PHOTOMOD (User Manual; http://www.racurs.ru) which was used for this study, proceeds with an image correlation analysis between each photo pair. by using a user defined grid. The correlation algorithm is based on observed grey levels, found within a search window. By choosing a minimum threshold, the user chooses the sensitivity of the automatic point picking process. Hence, a dense set of points can be quickly obtained, which allows the interpolation of a model, even if user inputs are necessary over areas with reduced texture or radiometry. Furthermore, correlation aberrations are seen where ground control or tie points are not numerous enough, leading to errors in altimetric determination. Many DEM generation methods are available but, in such a case, it is useful to compensate for correlation failures by interpolating points over the problematic areas.

\section{SELECTION OF THE EQUIPMENT AND ASSOCIATED ACCURACY}

The characteristics of each type of equipment has to be considered with respect to the study's goals. The most significant element is the focal length of the objective: it conditions the scale of the shots, depending on flight height. Then, film format and scale factor determines the ground extent of a shot. Finally, the number of necessary shots, the time delay between consecutive shots and the number of strips are affected by the choice of overlap and side-lap. Formulas expressing these different parameters are presented in Kraus and Waldhäusl, 1998.

\section{Choice of a camera.}

Table 1 shows the influence of focal length and film format on flight parameters, and demonstrates the importance of choosing the right equipment to obtain high quality results. Values have been calculated for a 500 meters above ground level flight height, at a speed of $35 \mathrm{~m} . \mathrm{s}^{-1}$ (i.e. $130 \mathrm{~km} \cdot \mathrm{h}^{-1}$ ) with a $70 \%$ overlap and a $40 \%$ side-lap. The items 'base' and ' $\mathrm{dT}$ ' correspond to the ground distance and the time delay between two shots, function of the speed of the aircraft. Parameters are determined for a flight path perpendicular to the valley axis to maintain, as far as possible, a constant scale factor over a whole strip. The different parameters are shown in Fig. 2a. 
HENRY, J.-B., MALET, J.-P., MAQUAIRE, O., GRUSSENMEYER, P., (2002). The use of small-format and low-altitude aerial photos for the realization of high-resolution DEMs in mountainous areas: application to the Super-Sauze earthflow (Alpes-de-Haute-Provence, France), Earth Surface Processes and Landforms ISSN: 0197-9337, Volume 27, Issue 12, pp. 1339-1350.

Table 1. Influence of focal length and film format on flight parameters

\begin{tabular}{|c|c|c|c|c|c|c|}
\hline Focal length & \multicolumn{2}{|c|}{$28 \mathrm{~mm}$} & \multicolumn{2}{|c|}{$50 \mathrm{~mm}$} & \multicolumn{2}{|c|}{$105 \mathrm{~mm}$} \\
\hline $\begin{array}{l}\text { Film format } \\
\text { Scale }\end{array}$ & \multicolumn{2}{|c|}{$\begin{array}{c}24 \times 36 \mathrm{~mm} \\
1 / 18000\end{array}$} & \multicolumn{2}{|c|}{$\begin{array}{c}24 \times 36 \mathrm{~mm} \\
1 / 10000\end{array}$} & \multicolumn{2}{|c|}{$\begin{array}{c}50 \times 60 \mathrm{~mm} \\
1 / 4700\end{array}$} \\
\hline & Hor.* & Ver.** & Hor. & Ver. & Hor. & Ver. \\
\hline Base (m) & 200 & 130 & 110 & 70 & 90 & 75 \\
\hline $\begin{array}{l}\text { Distance between } \\
\text { flight lines }(\mathrm{m})\end{array}$ & 260 & 390 & 145 & 215 & 145 & 170 \\
\hline $\mathrm{dT}(\mathrm{s})$ & 5 & 4 & 3 & 2 & 2 & 2 \\
\hline
\end{tabular}

* Hor. or horizontal, means that the camera is held so that the largest side of the negative is parallel to the flight path;

** Ver. or vertical, means the smallest side of the negative is parallel to the flight path.
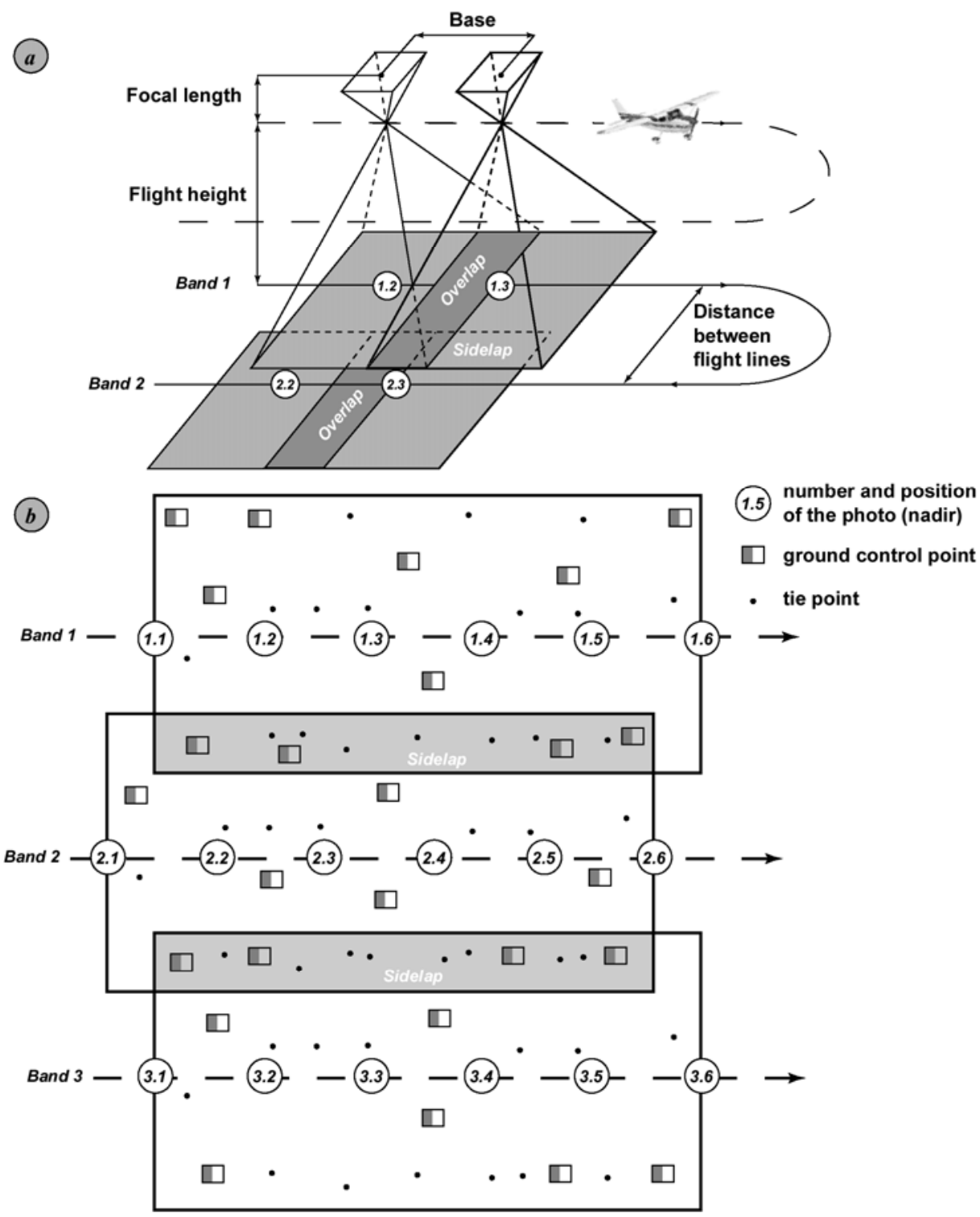

Fig. 2 - Flight parameters (a) and general localisation of ground control points and tie points (b) (adapted from Kraus, 1998)

\section{Camera calibration and constraints of digital processing.}

The equipment has to be calibrated, as accurately as possible, in a 3-D reference frame and in the same conditions as operational use, i.e. with focus set to infinite. The aim of this crucial step is to determine distortions generated by the optical system, hence the objective, and then to incorporate these into computations to minimise their influence on the final result (Fryer, 1996; Burnside and Marshall, 1992). Generally, errors are derived from selecting the points on calibration photos, and these are difficult to evaluate. The overall quality can only be appreciated through the final root mean square errors. Another way of calibrating a camera is to take advantage of the bundle block adjustment process flexibility. The inner orientation parameters can be treated as unknowns 
HENRY, J.-B., MALET, J.-P., MAQUAIRE, O., GRUSSENMEYER, P., (2002). The use of small-format and low-altitude aerial photos for the realization of high-resolution DEMs in mountainous areas: application to the Super-Sauze earthflow (Alpes-de-Haute-Provence, France), Earth Surface Processes and Landforms ISSN: 0197-9337, Volume 27, Issue 12, pp. 1339-1350.

in this method, and are computed using the whole set of equations. However, to initiate such a process, also called in-situ calibration, approximate values need to be entered.

Finally, to guarantee optimal digital processing; high resolution scanning is a prerequisite (2200 dpi, or a $11.55 \mu \mathrm{m}$ pixel).

\section{APPLICATION OVER A DIFFICULT TEST SITE: THE SUPER-SAUZE EARTHFLOW.}

The study site.

The Super-Sauze earthflow (Alpes-de-Haute-Provence, southeastern France) is occurring in a gullied torrential catchment within badlands. The earthflow covers a surface of 17 ha between altitudes of $2080 \mathrm{~m}$ (crown) and $1740 \mathrm{~m}$ (toe of the flow), with an average $25^{\circ}$ slope. Historically, if nothing happened to the unstable area in the 1950 's, block-falls and structural slides of large panels occurred in the 1960's. The accumulated material has evolved into a slow earthflow (Flageollet et al., 2000; Weber and Herrmann, 2000). Geo-technical and geophysical investigations (Schmutz et al., 2001), plus surface surveys (Malet et al., 2000; Malet et al., 2001) and in-depth displacement measurement indicate that the flow fossilizes an intact paleo-topography (Flageollet et al., 2000; Maquaire et al., in press) comprised of a succession of parallel crests and gullies.

The hydro-dynamical and geo-mechanical modelling requires a precise representation of the flow and its environment's relief. In 1999, a DEM of the flow was geodetically generated, with a $1 \mathrm{~m}$ resolution and a vertical precision of less than $5 \mathrm{~cm}$. The large area $\left(0.50 \mathrm{~km}^{2}\right)$ and its morphology (crests and gullies, Fig. 3) does not lend itself to a monitoring survey of the flow's environment, neither by tacheometry (several reference stations are needed), nor by GPS (orographic masks, hilly slopes). A photogrammetric digital reconstitution seemed to be the only efficient solution. The required precision for the flow environment's DEM was fixed at $30 \mathrm{~cm}$ in planimetry and $50 \mathrm{~cm}$ in altitude. This level of precision guided the choice of both the focal length and the various flight parameters.

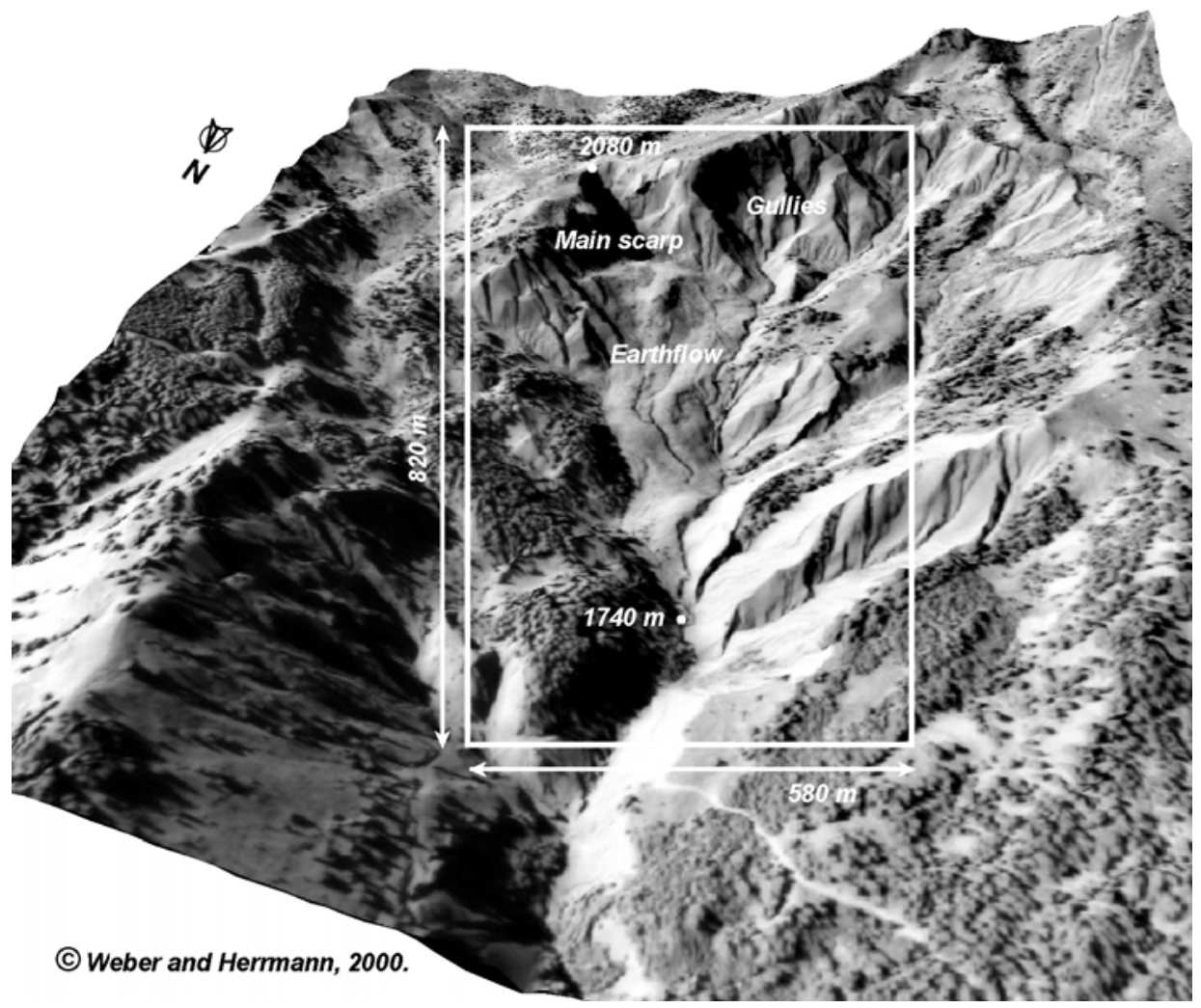

Figure 3 - The Super-Sauze earthflow study site: a torrential basin.

Technical choices

Flight parameter computation led to the choice of a small format, semi-metric and motorised RICOH KR-10M camera (i.e. with fiducial marks), with a $24 \times 36$ film and an amateur objective with a $50 \mathrm{~mm}$ focal length. Flight parameter values are cited on figure 4 . 
HENRY, J.-B., MALET, J.-P., MAQUAIRE, O., GRUSSENMEYER, P., (2002). The use of small-format and low-altitude aerial photos for the realization of high-resolution DEMs in mountainous areas: application to the Super-Sauze earthflow (Alpes-de-Haute-Provence, France), Earth Surface Processes and Landforms ISSN: 0197-9337, Volume 27, Issue 12, pp. 1339-1350.
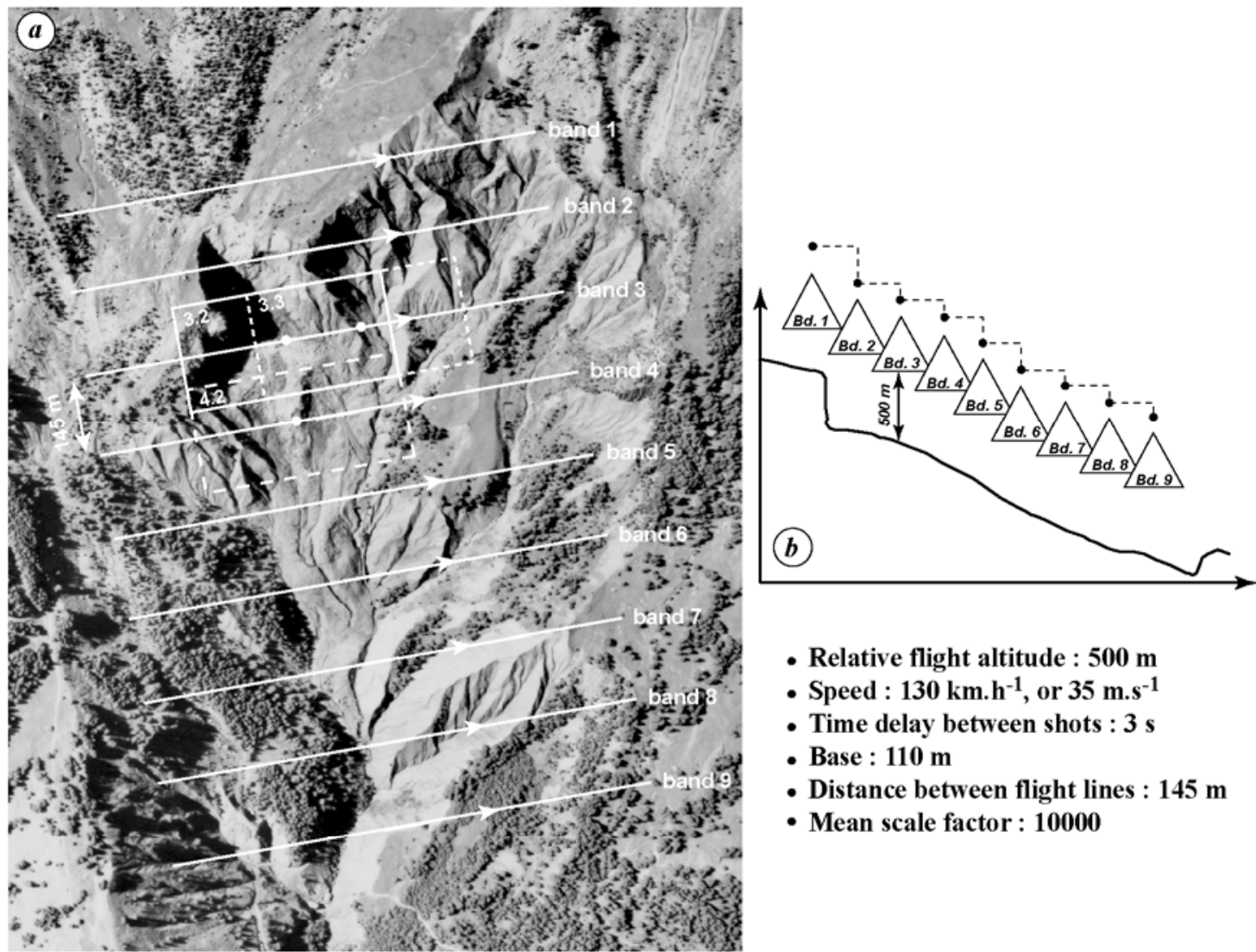

- Relative flight altitude : $500 \mathrm{~m}$

- Speed : $130 \mathrm{~km} \cdot \mathrm{h}^{-1}$, or $35 \mathrm{~m} \cdot \mathrm{s}^{-1}$

- Time delay between shots : $3 \mathrm{~s}$

- Base : $110 \mathrm{~m}$

- Distance between flight lines : $145 \mathrm{~m}$

- Mean scale factor : 10000

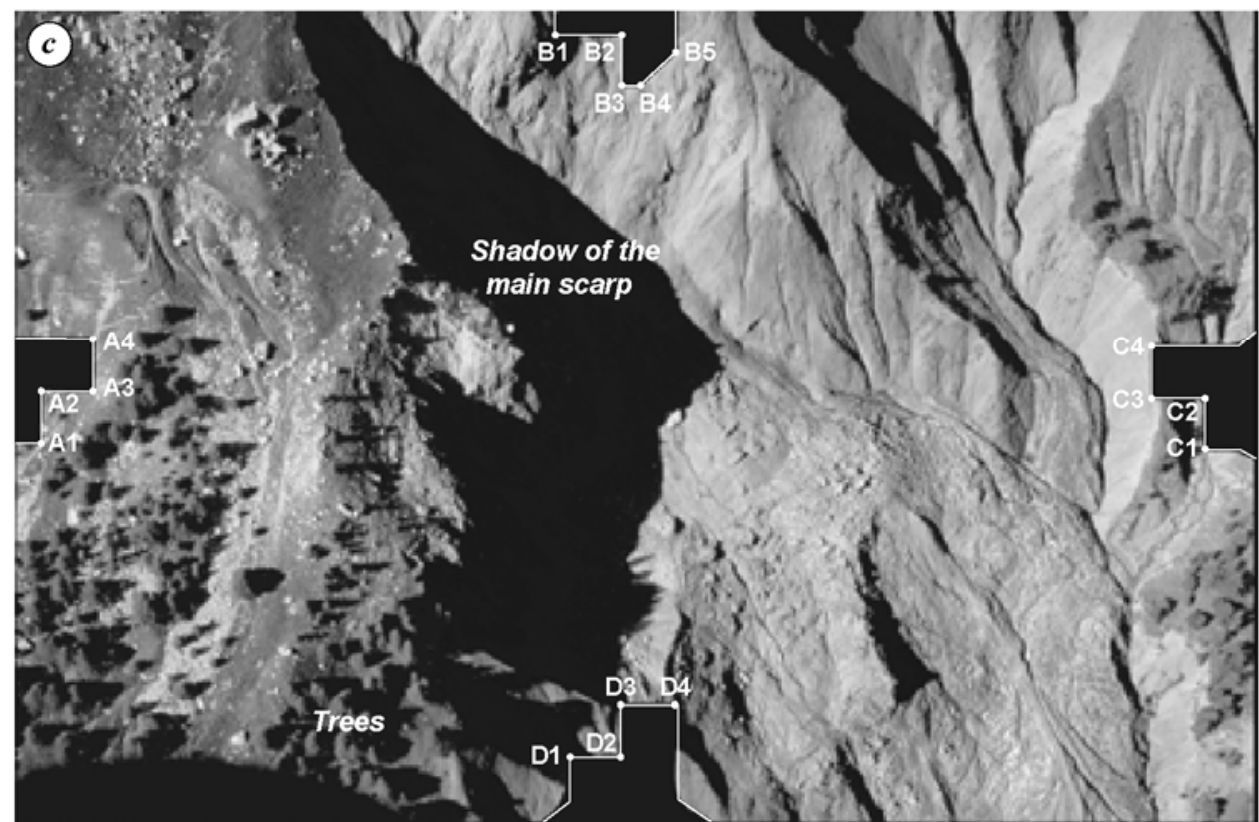

Fig. 4 - Flight paths (a) and decreasing altitudes (b).

Example of a photography (c) with four fiducial marks (noted A1-A4 , B1-B5; C1-C4; D1-D4)

Within the study area, a $800 \mathrm{~m}$ by $600 \mathrm{~m}$ rectangle, an important height differential is observed (400 m) between the crown and the toe of the flow. In order to reduce scale factor effects, it was decided to fly at a constant height above ground level (Fig. 4a and 4b). This was one of the difficulties related to the photographic flight, due to the lack of absolute positioning of the strips. Additionally, and because it was hand held, there was no sure and stable means to control the verticality of the camera's nadir. Considering illumination conditions (8h30 GMT, latitude $43^{\circ}$ North, early July), the photos were taken with 100 ISO films, an aperture set to f/5.6 and a shutter speed of $10^{-3} \mathrm{~s}$. These choices reduce the blurring of the photo due to camera motion. This can transform a point object into a streak, whose length depends on the exposure time of the emulsion, the plane's speed and the scale factor (Kraus and Waldhäusl, 1998). About sixty markers of $45 \times 45 \mathrm{~cm}^{2}$ were placed over the whole area. 
HENRY, J.-B., MALET, J.-P., MAQUAIRE, O., GRUSSENMEYER, P., (2002). The use of small-format and low-altitude aerial photos for the realization of high-resolution DEMs in mountainous areas: application to the Super-Sauze earthflow (Alpes-de-Haute-Provence, France), Earth Surface Processes and Landforms ISSN: 0197-9337, Volume 27, Issue 12, pp. 1339-1350.

\section{Aerotriangulation results.}

Aerotriangulation results are of quite good quality, but really satisfying considering the chosen materials. However, it can be noticed that on the model's sides (on first and last photos of each strip), preponderance of tie points and lack of ground control points seems to cause model drifting. Consequently, the global root mean square error $\sigma_{0}$ increases. This value integrates errors on the whole set of 3-D parameters and measures which are put into the aerotriangulation process $\left(\sigma_{0}=1,87 \mathrm{~m}\right)$. The root mean square error reaches respectively on the $\mathrm{X}$, Y and $\mathrm{Z}$ component $1,29 \mathrm{~m}, 1,75 \mathrm{~m}$ and $1,34 \mathrm{~m}$.

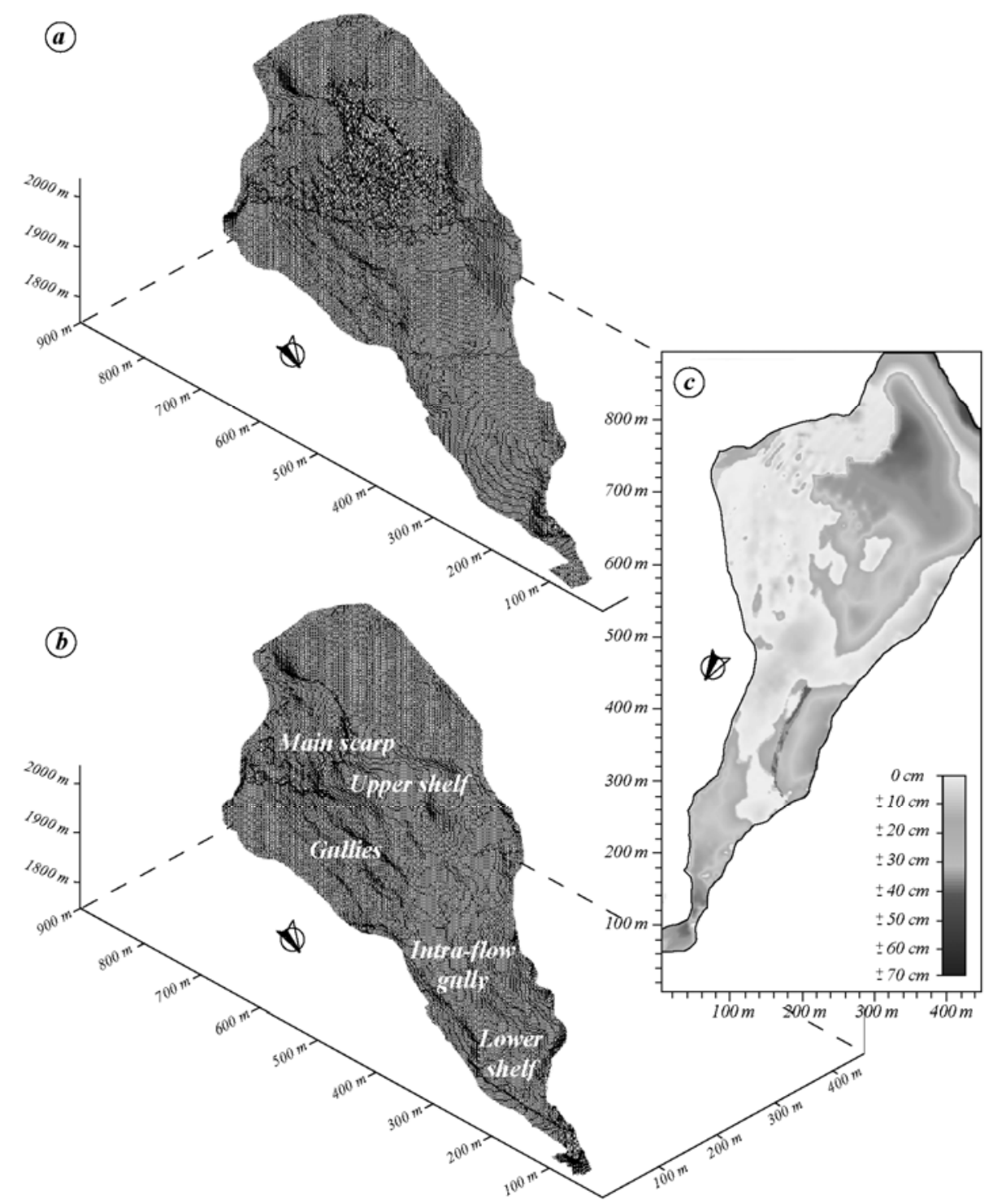

Fig. 5 - The photogrammetric DEM (a) and the tacheometric DEM (b) of the Super-Sauze earthflow. Z difference between the tacheometric and the photogrammetric DEM's (c).

Very large uncertainties concerning the determination of external orientation data (localisation and attitude of the camera for each photo) appear, because of the difficulty of providing approximate input values. The use of a GPS receiver turns out, one more time, to be useful for reliable approximate values which can initiate computations.

\section{Relative accuracy of DEM.}

Fully automated DEM generation was not as satisfactory as it was hoped, due to frequent correlation errors generally linked to image radiometry. These resulted in aberrant points in the DEM, detected by stereoscopic photo observation, on which would have been overlaid level lines from the calculated model. Because of the photo scale and of the study area's morphology, the global model was generated from each pair of photos by applying a 50×50 points interpolation grid. 
HENRY, J.-B., MALET, J.-P., MAQUAIRE, O., GRUSSENMEYER, P., (2002). The use of small-format and low-altitude aerial photos for the realization of high-resolution DEMs in mountainous areas: application to the Super-Sauze earthflow (Alpes-de-Haute-Provence, France), Earth Surface Processes and Landforms ISSN: 0197-9337, Volume 27, Issue 12, pp. 1339-1350.

Then the interpolation was completed and corrected by manual point inputs, and by data imports coming from tacheometric survey. Compared to the high density of the digitally generated point network, the proportion represented by manual and ancillary inputs do not exceed $2 \%$. Finally, where the set of topographic points overlap the photogrammetric set, differences of about $50 \mathrm{~cm}$ were noted. Figure 5 shows the $2 \mathrm{~m}$-DEM interpolated from the photogrammetric (5a) and tacheometric (5b) grid and figure 5c shows the $\mathrm{Z}$ difference between the two models. On the tacheometric DEM, considered as our reference model, where $\mathrm{Z}$ accuracy is evaluated to $5 \mathrm{~cm}$ (Malet et al., 2001), many morphological elements are visible: the main intra-flowing gully in the centre of the earthflow, the different shelves, ... On the photogrammetric model, if the global morphology of the earthflow is well represented, these particular forms are not clearly visible (the relative accuracy of the model tends to smooth out the detailed morphology). Thus the global accuracy of the photogrammetric DEM is evaluated as a sub-metric value. However, the chaotic nature of the area leads us to consider differences between photogrammetric and tacheometric DEM's employing more restrictive regional criteria, as shown in Table 2.

Table 2. Z difference for different morphological areas of the earthflow.

\begin{tabular}{lll}
\hline Area & Mean of $\Delta \mathrm{Z}$ & Std Deviation of $\Delta \mathrm{Z}$ \\
\hline A. Main scarp & $+41.3 \mathrm{~cm}$ & $14.0 \mathrm{~cm}$ \\
B. Intra-flowing gully & $+46.7 \mathrm{~cm}$ & $9.2 \mathrm{~cm}$ \\
C. Plain areas $\left(\right.$ slope $\left.<10^{\circ}\right)$ & $+7.8 \mathrm{~cm}$ & $4.2 \mathrm{~cm}$ \\
D. Sloping Areas $\left(\right.$ slope $\left.>10^{\circ}\right)$ & $-8.2 \mathrm{~cm}$ & $11.4 \mathrm{~cm}$ \\
\hline
\end{tabular}

Each area in table 3 shows major problems and difficulties that can be encountered in such an environment. Shadows of important morphologic elements are certainly the biggest nuisance (e.g. shadow of the main scarp hides a large area - Fig.4c -), trees on the sides create overground elements that make the DEM deviate. Table 2 shows also that where the quality of photos is good (i.e. with no shadows and a good radiometry), the difference between photogrammetric and tacheometric DEM's is less than $10 \mathrm{~cm}$.

\section{DISCUSSION: STRATEGIES AND PARTICULAR CARES.}

Photogrammetric techniques are perfectly usable for accurate DEM generation over wide areas, for spatialised dynamic cartography or for topographical monitoring of geophysical entities (glaciers, avalanches, mass movements, dunes). The proposed technique, which is based on the use of small format aerial photos, has the advantage of being quickly operational and rather cheap (without considering the photogrammetric software costs). The interest of this low-cost and flexible photogrammetric methodology lies in the possibility for the geomorphologist to have an improved reaction ability and productivity (amateur camera, standard films and objectives, with a plane without particular equipment such as a trap door); this ready-to-use methodology is essential for change detection or displaced volumes evaluation, after a particular event. Means required by this technique are light enough to be quickly mobilised, in order to cover an average area of about $2 \mathrm{~km}^{2}$.

Compared to conventional field surveys methods (topometry, GPS) photogrammetry has the indefinable advantage of being less time consuming on the field and for the post-treatments, of delivering a quasi continuous 3-D positioning and of delivering an orthophoto of the study site. Even if topometry and GPS surveying provide better accuracies (typically centimetric), they are not useful:

- if the study site is large or if the morphological situation is not adapted to optical measurements (several reference points and polygonal calculations are thus necessary and time consuming);

- if the study site is very hilly and provides environmental masks limiting sky visibility or creating multi-paths effects for GPS measurements.

If the needed accuracy is near $50 \mathrm{~cm}$ in the three directions (which is sufficient for most landscape geomorphological mappings and modelling studies) photogrammetry can be a useful "fit for purpose" tool because the cost/gain and time/gain ratios are low. In our case the photogrammetric DEM has been successfully used as input in a GIS based hydrological and geotechnical model (Malet et al., submitted) and has been used to derive with a good accuracy slope and local drainage direction maps.

Nevertheless the photogrammetric process remains subject to a lot of constraints and much care has to be taken, in the choice of the material and the flight parameters. The purpose is to choose the best camera characteristics and to make the best compromise between focal length, film format or film motorisation. Concerning the practical realisation of the photos, it is necessary to insist on the acquisition time. In wooded areas or with important relief, the elevation of the sun determines the size of shadows. So, it seems logical to fly at solar midday. From another point of view, the use of a GPS navigation receiver primarily aims to provide reliable approximate values of the position of each photo, but also to make easier the homogenous implantation of markers.

Then, the reader will notice that running of photogrammetric software is not as easy as it seems and adequation between software capabilities and project specifications must be carefully studied. Moreover, if more 
HENRY, J.-B., MALET, J.-P., MAQUAIRE, O., GRUSSENMEYER, P., (2002). The use of small-format and low-altitude aerial photos for the realization of high-resolution DEMs in mountainous areas: application to the Super-Sauze earthflow (Alpes-de-Haute-Provence, France), Earth Surface Processes and Landforms ISSN: 0197-9337, Volume 27, Issue 12, pp. 1339-1350.

than one pair of shots is necessary to survey the whole area, then it is compulsory to globally compute the model, e.g. by using of one of the aero-triangulation methods (Kraus and Waldhäusl, 1998).

Finally, the multiple sources of errors must be carefully considered in such a study; the range is extremely wide, from the micrometer, for inner orientation or photo point measuring, to tens of metres for correlation errors in DEM generation. This paper has tried to show the complexity of such a process, but also that it has successfully been performed over a difficult area with many constraints and limited means of action. Consequently, it appears capital for the reader to be fully aware of the requirements and limitations of this methodology, so as not to have illusions on the accuracy of the final result. However, it presents a good alternative for diachronic studies and for mapping a specific event.

\section{AKNOWLEDGMENTS}

This program was supported by the CNRS (Centre National de la Recherche Scientifique) in the framework of INSU program PNRN (Programme National Risques Naturels): 97/99-34MT. Contribution INSU NXX. The authors wish especially to thank J.-A. Quessette, of CHS Carto France Co., for his help during the processing and for the disposal of the aerotriangulation module for PHOTOMOD Software.

\section{REFERENCES}

Ackermann, F. and Schwiedefsky, K. 1974. Photogrammetrie. Teubner Verlag, Stuttgart.

Ammann, W.J. 1999. A new Swiss test-site for avalanche experiments in the Vallée de la Sionne (Valais), Cold Regions Science and Technology, 30, 3-11.

Burnside, C.B. and Marshall, M.P. 1992. Experiences in calibrating small format cameras, Photogrammetric Record, 80, 323-331.

Chandler, J. 1999. Effective application of automated digital photogrammetry for geomorphological research, Earth Surface Processes and Landforms, 24, 51-63.

Chandler, J., Cooper, M.A.R. and Robson, S. 1989. Analytical aspects of small format surveys using oblique aerial surveys, Journal of Photographic Science, 37; 235-240.

Flageollet, J.-C., Malet, J.-P. and Maquaire, O. 2000. The 3-D structure of the Super-Sauze earthflow: a first stage towards modelling its behaviour, Physics and Chemistry of the Earth, Part B, 25 (9), 785-791.

Fruneau, B., Achache, J. and Delacourt, C. 1996. Observation and modelling of the Saint-Etienne-de-Tinée landslide using SAR interferometry, Tectonophysics, 265, 181-190.

Fryer, J.G., 1996, Chapter 6: Camera Calibration, monograph Close Range Photogrammetry and Machine Vision, Whittles Publishing, p. 156-180.

Goudie, A. (Ed.). 1990. Geomorphological Techniques, British Geomorphological Research Group, p. 570.

Graham, R.W. and Read, R.E. 1984. Small format aerial surveys from light and microlight platforms. Journal of Photographic Science, 32 (3), 100-110.

Heimes, F.J., Poole, P., Brechtken, R. and Puruckherr R. LEO: Local Earth Observation, in Proceedings of the International Symposium "Operationalization of Remote-Sensing", ITC, Entshede, The Netherlands, p. 5664.

Karara, H.M. 1980. Non-metric cameras. In Atkinson, K.N. (Ed.), Developments in Close Range Photogrammetry, Applied Science Publishers, London, 63-80.

Kraus, K. and Waldhäusl, P. 1998. Manuel de photogrammétrie, Traduction de P. Grussenmeyer et O. Reis, Editions Hermès Paris, p. 407.

Lane, S.N., Chandler J.H. and Richards, K.S. 1998. Landform monitoring, modelling and analysis: land form in geomorphological research. In Lane, S.N., Richards, K.S. and Chandler J.H. (Eds.), Landform Monitoring, Modelling and Analysis, Wiley, Chichester, 1-18.

Malet, J.-P., Hartig, S., Calais, E. and Maquaire, O. 2000. Apport du GPS au suivi en continu des mouvements de terrain. Application au glissement-coulée de Super-Sauze (Alpes-de-Haute-Provence, France), ComptesRendus de l'Académie des Sciences, 331, 175-182.

Malet, J.-P., Maquaire, O. and Calais, E. 2002. The use of Global Positioning System techniques for the continuous monitoring of landslides. Application to the Super-Sauze earthflow (Alpes-de-Haute-Provence, France), Geomorphology, 43, 33-54.

Malet, J.-P., Locat, J., Remaître, A., Maquaire, O. Dynamics of distal debris-flow associated to the Super-Sauze earthflow. Implications for landslide hazard assessment, Proceedings of the First International Conference on Fast Slope Movements Predicition and Prevention for Risk Mitigation, Sorrento, May, 16-17, 2002, p. 8 (submitted).

Maquaire, O., Flageollet, J.-C., Malet, J.-P., Schmutz, M., Weber, D., Klotz, S., Guérin, R., Descloîtres, M., Schott, J.-J., Albouy, Y. and Dietrich, M. Une approche multidisciplinaire (géomorphologie, photogrammétrie numérique, géotechnique, géophysique) pour la connaissance d'un glissement-coulée dans 
HENRY, J.-B., MALET, J.-P., MAQUAIRE, O., GRUSSENMEYER, P., (2002). The use of small-format and low-altitude aerial photos for the realization of high-resolution DEMs in mountainous areas: application to the Super-Sauze earthflow (Alpes-de-Haute-Provence, France), Earth Surface Processes and Landforms ISSN: 0197-9337, Volume 27, Issue 12, pp. 1339-1350.

les marnes noires (Super-Sauze, Alpes-de-Haute-Provence, France), Revue Française de Géotechnique, 95/96, 15-31.

McCullagh, M.J. 1998. Quality, use and visualization in terrain modelling. In Lane, S.N., Richards, K.S. and Chandler J.H. (Eds.), Landform Monitoring, Modeling and Analysis, Wiley, Chichester, 95-117.

Mendonçà Santos, M.L., Guenat, C., Bouzelboudjen, M. and Golay, F. 2000. Three-dimensional GIS cartography applied to the study of the spatial variation of soil horizons in a Swiss floodplain, Geoderma, 97, 351-366.

Mohr, J.J., Reeh, N. and Madsen, S.N. 1998. Three dimensional glacial flow and surface elevation measured with radar interferometry, Nature, 391 (6664), 273-276.

Palacio-Prieto, J.L. and López-Blanco, J. 1994. using video imagery for gully erosion evaluation, Zeitschrift für Geomorphology, 38 (1), 33-43.

Petrie, G. and Price, R.J. 1966. Photogrammetric measurements of the ice wastage and morphological changes near the Casement glacier, Alaska, Canadian Journal of Earth Sciences, 3, 783-798.

Powers, P.S., Chiarle, M. and Savage, W.Z. 1996. A digital photogrammetric method for measuring horizontal surficial movements on the Slumgullion earthflow, Hinsdale County, Colorado, Computers and Geoscience, 22 (6), 651-663.

Pyle, C.J., Chandler, J.H. and Richards, K.S. 1997. Digital photogrammetric monitoring of river bank erosion. Photogrammetric Record, 15, 753-764.

Rowe, J.P., Warner, T.A., Dean, D.R. and Egan, A.F. 1999. A remote sensing strategy for measuring logging road system length from small-format aerial photography, Photogrammetric Engineering and Remote Sensing, 65 (6), 694-703.

Schmutz, M., Albouy, Y., Guérin, R., Maquaire, O., Vassal, J., Descloîtres, M., Schott, J-J. 2001. Contribution of electrical and TDEM methods employed separately and combines to Super Sauze flowslide knowledge, Surveys in Geophysics, 21, 371-390.

Tapponnier P., de Voogd, B. and Hirn, A. 1999. Géologues et sismologues au Tibet, Sciences Actualités, 99 (9), 104-126.

Walker, J.-P. and Willgoose, G.R. 1999. On the effect of digital elevation model accuracy on hydrology and geomorphology, Water Resources Research, 35 (7), 2259-2268.

Webb, E.K. 1995. Simulation of braided channel topology and topography, Water Resources Research, 31 (10), 2603-2611.

Weber, D. and Herrmann, A. 2000. Reconstitution de l'évolution géomorphologique de versants instables par photogrammétrie numérique: l'exemple du glissement de terrain de Super-Sauze (Alpes-de-Haute-Provence, France), Bulletin de la Société Géologique de France, 171 (6), 637-648.

Welch, R. and Jordan, T.R. 1983. Analytical non-metric close range photogrammetry for monitoring stream channel erosion, Photogrammetric engineering and Remote Sensing, 49 (3), 367-374. 